\title{
A Municipal Audit Fee Model Using Structural Equation Modeling
}

Gary Giroux, Texas A\&M University

Andrew McLelland, Auburn University

\begin{abstract}
The purpose of this project is to model municipal audit fees using an audit economics framework and then analyze this conceptual framework empirically using structural equation modeling, because structural equation models are excellent for examining complex and interdependent environments. The sample is large cities using 1996 data. The theoretical model uses five constructs to explain audit fees: (1) client size, (2) complexity of client operations, (3) financial risks including demographic characteristics, (4) auditing factors, and (5) governance structure. The final model includes six variables directly related to audit fee plus five mediating variables. The results demonstrate that SEM modeling can explain audit fees and provides more information on how the highly correlated independent variables are interrelated in the context of explaining audit fee levels.
\end{abstract}

\section{INTRODUCTION}

overnmental audit fee models are well established in the literature. Most are run with large numbers of independent variables, usually a dozen or more. For example, Ward et al. (1994) used a 21-variable model to analyze audit fees of Michigan cities. A possible rationale for researchers to use big models is that with a large sample size, most variables are statistically significant. Despite obvious correlation across variables, standard diagnostics (e.g., variance inflation factors) generally don't indicate a multicollinearity problem when using regression.

In a large-variable framework, this approach can be considered conceptually inferior to a more detailed analysis available through structural equation modeling (SEM). Important conceptual issues and interrelationships should be explored to better understand how audit fees are structured. The purpose of this project is to model municipal audit fees using an audit economics framework and then explore this conceptual framework empirically using SEM. SEM has not been used in the context of audit fees and should be relevant given the complexity of the model building. In addition to the analysis of direct effects analyzed in regression, the indirect effects should have important implications on multidimensional relationships. A sample of large cities using data from 1996 is used for analysis. Although there are several auditing studies (and an occasional governmental study) that use SEM, none of these focuses on audit fees and few use archival data.

Our investigation is important for several reasons. First, there are relatively few governmental fee studies and each generally tests different types of governments for different time periods. Second, the SEM approach provides information on the interrelations across important variables. Third, the SEM results will be compared to OLS regression, a typical approach for analyzing audit fees. The comparison will demonstrate the relative strengths and weaknesses of the two approaches.

When interested only in the direct effects of independent variables on audit fees, OLS regression usually would be preferred to SEM. In fact, the direct effects SEM explanatory power as measured by $\mathrm{R}^{2}$ is usually similar to OLS without the complexity of evaluating indirect effects and covariation across exogenous variables. 
The SEM approach concentrates on model fit, based on standardized coefficient evaluation, goodness of fit statistics, and other diagnostics. SEM provides a much richer analysis of the municipal audit environment, incorporating the mediation processes (indirect effects) determined simultaneously in the model. For example, population has both a substantial direct effect on audit fees and indirect effects through client complexity (component units) and big 6 auditors. Governance structure has no direct effect on audit fees, but the empirical surrogate, city manager, influences audit fees through client complexity (tax share) and financial risk (financial viability). Thus, a seemingly insignificant variable city manager, influences audit fees.

The next section reviews the literature on audit fee and SEM in auditing. Section three provides model development based on audit economics theory and previous literature. Section four describes the sample. Section five explains the SEM approach and other empirical methods used for analysis. Section six analyzes the results and the last section concludes.

\section{MODEL DEVELOPMENT}

Empirical testing of audit fee models started with Simunic (1980) using commercial firms and Baber et al. (1987) using local governments. The current audit fee model uses five theoretical constructs to explain the level of audit fees. The theoretical constructs and specific variables selected are based on their use in prior studies. ${ }^{1}$ The five constructs are: (1) client size, (2) complexity of client operations, (3) financial risks including demographic characteristics, (4) auditing factors, and (5) governance structure. Client size should be associated with audit complexity. Larger organizations require more audit effort because there are more transactions. Complex client operations are expected to require more audit time and greater expertise, both expected to increase the cost of the audit. Auditors are increasingly focusing on financial risk to determine the level of audit effort (e.g., internal control checks and substantive testing) and audit pricing (Rubin 1988, Deis and Giroux 1996). There are several auditing factors that can influence audit fees. The type of auditor's opinion, whether this is a first year audit, and whether a Big 6 auditor is used are examples. Finally, the governance structure is expected to influence many factors related to client complexity and financial risk and, therefore, audit effort and price. The initial model, including empirical surrogates used to test the theoretical constructs, is presented in Table 1.

Table 1

Initial Model

\begin{tabular}{|l|l|c|}
\hline \multicolumn{1}{|c|}{ Theoretical Construct } & \multicolumn{1}{|c|}{ Empirical Surrogate } & \multicolumn{1}{|c|}{$\begin{array}{c}\text { Expected } \\
\text { Sign }\end{array}$} \\
\hline I. Client Size & Population (LNPOP) & + \\
\hline II. Complexity of Client Operations & Own Source Revenues per Capita (TAXSHARE) & + \\
\hline & Defined Benefit Pensions Overfunded Dummy (PENSION) & + \\
\hline & Component units (COMPUNIT) & + \\
\hline $\begin{array}{l}\text { III. Financial Risk (including Demographic } \\
\text { Characteristics) }\end{array}$ & Debt outstanding per capita (DEBTPC) & + \\
\hline & Financial viability (FV) & - \\
\hline & Surplus/deficit (SURDEF) & - \\
\hline & Average Income (AVGINC) & - \\
\hline & Population change, 1990-96 (CPOP) & $\mathbf{?}$ \\
\hline IV. Auditing Factors & Audit Opinion (AUDOPN) & - \\
\hline & Big 6 Auditor (BIG6) & + \\
\hline & Initial Audit (FIRSTYR) & - \\
\hline & Busy Season (BSAUD) & - \\
\hline V. Governance Structure & City Manager or Mayor (MGR) & - \\
\hline & Certificate of Achievement (CA) & - \\
\hline
\end{tabular}

The log of audit fees (LNFEE) is used as the dependent variable. Population is used to capture relative client size. The log of population (LPOP) is used in the multivariate analysis to control for skewness. Following Rubin (1988), Bamber et al. (1993) and McLelland and Giroux (2000), a positive sign is expected. 
Three variables are used as surrogates for the complexity of the municipalities' operations. Own source taxes usually represent the most stable revenue source and also demonstrate the relative wealth of the government. TAXSHARE is own source revenues per capita, as measured by (total revenue less intergovernmental grants) / population. It is not clear what the effect on audit fees is. Higher audit fees associated with a higher local revenue stream may represent more transactions to audit; alternatively, TAXSHARE may indicate more sophisticated financial-related technology that improves audit efficiency. No sign is predicted. Defined benefit pension plans are complex, require additional audit time, and increase financial risk when under funded. PENSION is measured as a dummy variable where $1=$ an over funded defined benefit pension plan. An under funded plan suggests greater audit risk; therefore, the coefficient should be negative. Component units are legally separate organizations for which the elected officials of the primary government are financially accountable (Government Accounting Standards Board Statement No. 14, 1991). The number of component units reported by the city is used (COMPUNIT), a measure of additional complexity and additional audit effort to comply with GASB No. 14. The additional audit time required should result in a positive sign (McLelland and Giroux, 2000).

Five variables are used as proxies for financial risk, three related to financial characteristics of the city plus two demographics factors. Debt per capita (DEBTPC) is used to proxy for credit risk. Higher debt levels are associated with greater credit risk and a positive sign is expected. Financial viability (FV), defined as the ratio of general fund equity divided by general fund revenues, is used as an empirical surrogate for financial condition (McLelland and Giroux, 2002). The relative equity position in the general fund is an indicator of financial health, roughly analogous to retained earnings for a commercial firm. A low measure can signal fiscal stress, increasing audit risk. A negative sign is expected. Running a current fiscal-year deficit should indicate increasing financial risk. Surplus/deficit (SURDEF) is measure as revenues/expenditures. A value of one represents a balances budget, greater than one a surplus, and less than one a deficit. A negative sign is predicted.

Demographic characteristics represent the economic base of the city, both related to potential revenues and relative spending requirements. The two measures are average income and population change. Average income (AVGINC) is a proxy for financial strength and a negative coefficient expected in the fee model, associated with lower audit risk (Baber et al. 1987, Deis and Giroux 1996). Income levels are usually associated with greater financial health and a negative coefficient is predicted. Population change (CPOP) should capture the relative population dynamics. "Rust belt" cities typically have declining populations, while "sunbelt" cities often have growing populations. Both substantial increases and decreases in population may cause disruptions that could increase audit risk and no sign is predicted.

Three auditor-related variables which are common in the literature are analyzed. The audit opinion (OPINION) is a dummy variable, where $1=$ a clean opinion. A qualified opinion indicates audit problems and should be associated with greater audit risk and therefore a higher fee. In most audit fee studies, a premium for a BIG6 auditor is found, usually associated with the reputation effect (e.g., Copley et al. 1995). An initial audit (FIRSTYR) may be associated with "low balling," which would reduce audit fees (DeAngelo 1981). A positive sign is predicted for BIG 6, a negative sign for OPINION and FIRSTYR. The auditor busy season generally extends from January to April, but audit fee results are mixed (McLelland and Giroux 2000). We measure busy season (BSAUD) as a dummy variable coded 1 when the fiscal year-end of the city is between October 31 and December 31. It is expected that a busy season audit will increase audit fees.

The alternative governance structures (MGR) in cities are (1) city manager and (2) mayor-council. The mayor-council form means that the chief executive is elected and presumably is interested in reelection. The city manager is a full-time professional manager. The city manager structure has obvious principal-agent relationships, with the city manager the agent of the city council (Selden et al., 1999). This should be associated with a strong financial structure free of fiscal stress, relatively low taxes and low debt levels, a problem-free audit, and financial reports that signal complete reporting in a competent manner. The mayor-council governance structure should be associated with a focus on political rather than financial characteristics, such as meeting the needs of important special interests. Therefore, there are few obvious incentives to achieve a strong financial structure. Assuming that governance structure incentives predominate (that is, regulatory environment and economic conditions are relatively less important), the city manager form should result in lower audit costs and a negative sign expected. 
Cities can sign up to be inspected for a Certificate of Achievement (CA), indicating excellence in financial reporting for those receiving the $\mathrm{CA}$. Receiving a CA suggests a city committed to transparency and implies lower audit risk. A negative coefficient is forecast.

\section{SAMPLE}

To test the audit fee model, we use a national sample of cities with populations exceeding 100,000 for the fiscal year ending in 1996. The 1996 period was over a decade after significant regulatory changes and was well into the economic boom of the 1990s. Annual reports were received from 166 cities in 1996 over 100,000 in population. One hundred and forty-one cities responded to an audit fee questionnaire. Non-response testing indicated no difference in the two samples. One city with missing information was eliminated, reducing the final sample to 140. Small sample size is an issue with SEM and standard rules of thumb suggest a minimum 100 or 200 observations to generate valid goodness of fit measures (Smith and Langfield-Smith 2004). To compensate for the relatively small sample size, multiple goodness of fit measures are analyzed (Donnelly et al. 2003).

\section{METHOD}

The variable of interest is audit fees for 1996. Audit fees are expected to be explained based on the theoretical constructs associated with client size, operating complexity of the client, financial risks, auditing factors, and municipal governance structure. Fourteen empirical variables are initially used to test the five constructs identified in the theoretical model. Descriptive statistics for these variables include mean, standard deviation, and range.

Multivariate analysis uses a structural equation modeling (SEM) procedure. $^{2}$ Four steps are used to construct the SEM model: (1) model specification; (2) model identification; (3) goodness of fit; and (4) model modifications. Model development is based on expected theoretical relationships and correlations as measures of potentially significant relationships; consequently, a correlation matrix is shown and evaluated. Multivariate analysis includes SEM and an OLS regression analysis for comparison. ${ }^{3}$ The OLS models use the same variables identified in the initial and final SEM models. Stepwise regression also is used to come up with an OLS-generated parsimonious model.

Figure 1 is used as the starting point to develop the SEM model specification. This is a path diagram based on the theoretical model building described above. There are five theoretical constructs, each representing a latent variable (that is, the theoretical constructs not directly observable) and presented in the ovals. Specific empirical surrogates to test these relationships are in the rectangles, with expected directional relationships shown by arrows. These relationships will be refined through the iterative SEM process.

Correlation analysis is used to understand basic empirical relationships across the variables under study. Correlations are used as the starting point for converting the theoretical model to SEM testing. Significant relationships are used to construct a new path diagram to be empirically tested using CALIS, the SEM program available on SAS. The analysis takes multiple iterations to determine the best available model (model trimming), using maximum likelihood (ML) estimation. A key consideration is the various indirect effects that are modeled using SEM, but would be ignored when using standard regression procedures. Statistical diagnostics based on covariance analysis are extensive and the final model should include all significant relationships of theoretical interest. As part of the SEM process, latent structures were evaluated using confirmatory factor analysis. These performed poorly and are not used. This analysis uses only empirical (also called observed or manifest) variables.

The SEM approach provides preliminary results, including a thorough set of diagnostics. The overall model includes a set of goodness of fit tests, such as the goodness of fit index. The model fit is evaluated with the standardized coefficient estimates based on maximum likelihood. The exogenous variables are not evaluated, but the covariances of exogenous variables are reviewed to determine if these relationships should be incorporated in the overall model. Additional tests are used to consider all potential fits of variables not in the original model and the impact of the error terms. The key is significant relationships. Insignificant relationships generally are deleted and all significant relationships are included (these are usually done one variable at a time since all relationships are tested simultaneously). 
Figure 1

Conceptual Audit Fee Model (Simplified)

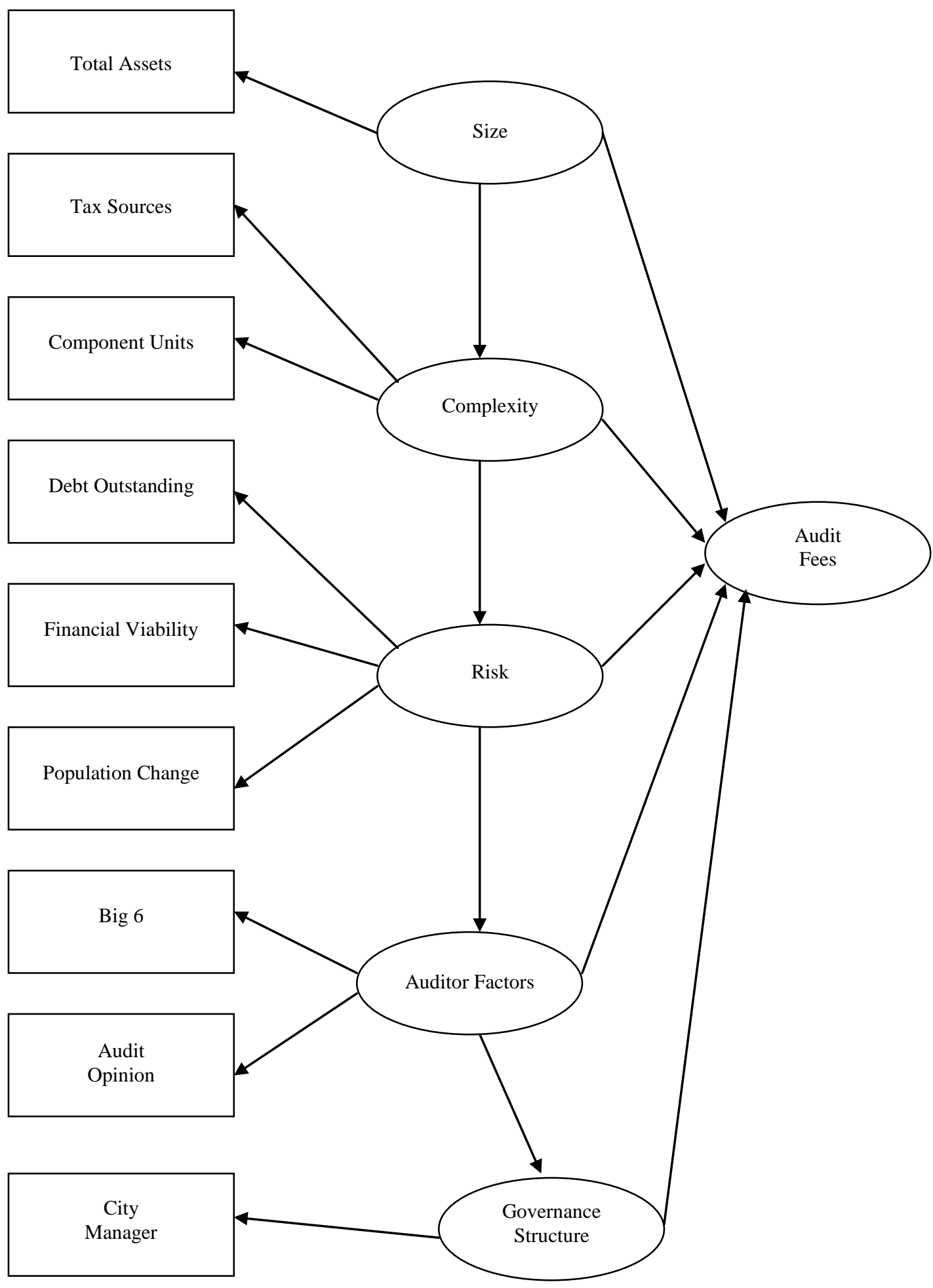




\section{RESULTS}

Results include an analysis of both univariate and multivariate analysis. Univariate tests include a descriptive analysis and correlations. Multivariable results are based on the SEM model, which are compared to OLS regression results. Univariate results are summarized in Tables 2 (descriptive) and 3 (correlations). The final SEM results are summarized in Figure 2 and OLS results in Tables 4 and 5.

\section{Univariate Results}

Table 2 summarizes univariate results for the sample of 140 large cities with complete data. The average audit fee was almost $\$ 120,000$, with a large range of $\$ 21,000$ to over $\$ 1$ million. Descriptive results worth reviewing include the following. Over $64 \%$ of the cities were under funded, an unexpected finding given a robust economy. Ninety-three per cent of the cities had unqualified opinions, with only ten modified reports. The Big 6 audited $75(53.6 \%)$ of the large cities, and 17 cities (12.1\%) changed auditors in 1996. Eighty-three cities used city managers (59.3\%), while $119(85.0 \%)$ received a Certificate of Achievement.

Table 2

Descriptive Analysis (n=140)

Panel A: Continuous Variables

\begin{tabular}{|c|c|c|c|c|}
\hline Variable & Mean & $\begin{array}{c}\text { Standard } \\
\text { Deviation }\end{array}$ & Minimum & Maximum \\
\hline Audit Fee & $\$ 119,598$ & 146,634 & 21,000 & $1,075,000$ \\
\hline Population & 310,879 & 428,048 & 100,000 & $3,554,000$ \\
\hline Tax Share & $\$ 692$ & 356 & 231 & 2,352 \\
\hline Component Units & 4.48 & 3.82 & 0 & 26 \\
\hline Debt Outstanding per Capita & $\$ 887$ & 639 & 80 & .0004 \\
\hline Financial Viability & $28.7 \%$ & 0.287 & 0.69 & 1.693 \\
\hline Surplus/Deficit & 1.02 & 0.08 & 6,284 & 1.26 \\
\hline Average Income & $\$ 14,283$ & 3,474 & -0.107 & 27,092 \\
\hline Population Change & $7.2 \%$ & 0.119 & & .877 \\
\hline
\end{tabular}

Panel B: Dummy Variables

\begin{tabular}{|c|c|c|}
\hline Variable & Frequency (\# 1/Yes) & \% of 1/Yes \\
\hline Pensions - Overfunded & 50 & $35.7 \%$ \\
\hline Unqualified Audit Opinion & 130 & 52.9 \\
\hline Big 6 Auditor & 75 & 53.6 \\
\hline Initial Audit & 17 & 12.1 \\
\hline City Manager & 83 & 59.3 \\
\hline Certificate of Achievement & 119 & $85.0 \%$ \\
\hline
\end{tabular}

Correlations based on Pearson's are summarized in Table 3. Correlations are a major factor in determining the initial SEM models. Many variables were correlated with audit fees. Three variables were significantly correlated at .0001 included population, tax share, and debt per capita. Five additional variables were correlated at .1. Population change was negatively correlated with audit fee, suggesting that high-growth cities required less extensive audit effort. All other correlations were in the expected direction (component units, financial viability, Big 6, and city manager). An analysis of correlations across the independent variables was used to model the other relationships across the audit fee spectrum. For example, population was correlated with several of the other variables, as were financial viability, population change, Big 6, and manager. These are likely to be mediating variables (that is, they affect some variables and are affected by others) within the audit fee process. 
Table 3

Correlation Matrix (Pearson's)

\begin{tabular}{|c|c|c|c|c|c|c|c|c|c|c|c|c|c|c|c|}
\hline & $\stackrel{a}{2}$ & 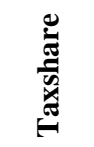 & 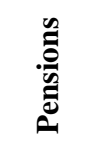 & 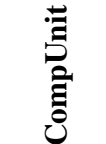 & 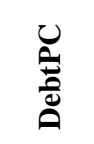 & 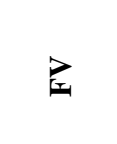 & 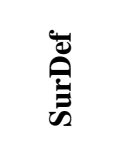 & $\underset{Z}{\mathscr{E}}$ & 气̊ & 范 & $\begin{array}{l}0 \\
000 \\
00\end{array}$ & 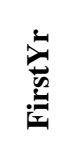 & 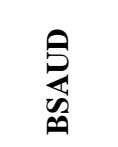 & $\sum^{500}$ & త্ \\
\hline Audit Fee & $62.9 *$ & $42.2 *$ & -4.4 & $16.3^{* *}$ & $23.2 *$ & $-24.7 * *$ & -7.9 & 1.9 & $-18.9 * *$ & 4.1 & $28.4 * *$ & 6.7 & 8.0 & $-29.0 * *$ & 10.3 \\
\hline Population & - & 12.3 & -11.1 & 28.0 & 12.6 & $-17.9 * *$ & 3.6 & -2.5 & -8.3 & 7.6 & $16.5 * *$ & 6.8 & 4.1 & -17.8 & 11.8 \\
\hline Taxshare & & - & -0.9 & 3.0 & $45.5^{*}$ & $-21.5 * *$ & -9.6 & $27.4^{* *}$ & $-23.1 * *$ & 0.4 & $31.2 * *$ & 6.6 & 4.0 & $-32.5^{*}$ & 5.7 \\
\hline Pensions & & & - & -4.7 & 2.2 & $25.7 * *$ & $-17.7 * *$ & $20.8^{* *}$ & 5.2 & 3.3 & -11.3 & -9.5 & $-23.8^{*}$ & $22.3^{* *}$ & -6.3 \\
\hline Comp Unit & & & & - & -3.0 & -12.9 & 2.8 & -11.8 & $-16.3 * *$ & 2.0 & 14.0 & -4.7 & 8.5 & -10.6 & -15.2 \\
\hline Debt PC & & & & & - & -1.6 & -10.8 & 1.3 & 7.5 & -2.5 & $14.6 * *$ & 6.8 & -4.1 & -19.0 & 4.9 \\
\hline FV & & & & & & - & 9.3 & $18.8^{* *}$ & $20.0 * *$ & 2.7 & -14.9 & -6.1 & $-19.9 * *$ & $25.4 * *$ & 2.3 \\
\hline Sur/Def & & & & & & & - & 11.5 & $25.2 * *$ & -2.4 & 3.5 & -0.2 & -9.5 & 5.5 & 2.3 \\
\hline Avg Inc & & & & & & & & - & 12.2 & $19.6^{* *}$ & 8.9 & -4.8 & -11.2 & 9.2 & 16.9 \\
\hline Pop Chg & & & & & & & & & - & 9.1 & 4.4 & 4.1 & $-20.4 * *$ & 21.1 & 12.5 \\
\hline Opinion & & & & & & & & & & - & 13.1 & -6.7 & 2.3 & 10.9 & 66.0 \\
\hline Big 6 & & & & & & & & & & & - & 3.9 & -9.0 & 1.6 & 13.0 \\
\hline First Year & & & & & & & & & & & & - & -10.3 & -0.4 & 3.4 \\
\hline Manager & & & & & & & & & & & & & $-22.5^{*}$ & - & 14.0 \\
\hline$\overline{\mathrm{CA}}$ & & & & & & & & & & & & & -9.7 & & - \\
\hline
\end{tabular}

* Significant at .0001; ** Significant at .1 


\section{SEM Results}

The initial audit fee SEM model, based on the variables in Figure 1 and correlations (i.e., to identify significant relationship), contains the following equations:

Initial SEM Model used:

LNFEE $=\beta_{1}$ LNPOP $+\beta_{2}$ FV $+\beta_{3}$ TAXSHARE $+\beta_{4}$ PENSION +

$\mathrm{B}_{5}$ COMPUNIT $+\beta_{6}$ DEBTPC $+\beta_{7}$ FV $+\beta_{8}$ SURDEF $+\beta_{9}$ AVGINC +

$\mathrm{B}_{10}$ CPOP $+\beta_{11}$ AUDOPN $+\beta_{12}$ BIG6 $+\beta 13$ FIRSTYR $+\beta_{14}$ BSAUD

$+\beta_{15} \mathrm{MGR}+\beta_{16} \mathrm{CA}+\mathrm{e} 1$

$\mathrm{FV}=\beta_{17} \mathrm{MGR}+\mathrm{e} 2$

TAXSHARE $=\beta_{18} \mathrm{MGR}+\beta_{19} \mathrm{FV}+\beta_{20}$ DEBTPC $+\mathrm{e} 3$

BIG6 $=\beta_{21}$ LPOP $+\beta_{22}$ FV $+\beta_{23}$ TAXSHARE + e 4

COMPUNIT $=\beta_{24}$ LNPOP + e5,

where $\alpha=$ intercept, $\beta=$ coefficient and $\mathrm{e}=$ error term.

The sixteen empirical surrogates are potentially associated with audit fees. Four additional equations are added to test possible indirect effects, based on previous literature and the evaluation of correlations.

As expected, the initial SEM model was not robust. Most goodness of fit tests were weak and many of the independent variables were insignificant. For example, only six of the initial independent variables had significant t-values for explaining audit fees. Relatively large correlations among the exogenous variables required additional analysis. Consequently, we made additional runs to refine the model. The result is a much simpler model, based on significant and theoretically defensible relationships. The final SEM equations are:

$$
\begin{aligned}
& \text { LNFEE }=\beta_{1} \text { LNPOP }+\beta_{2} \text { FV }+\beta_{3} \text { TAXSHARE }+\beta_{4} \text { COMPUNIT }+ \\
& B_{5} \text { CPOP }+\beta_{6} \text { BIG6 }+ \text { e } 1 \\
& \text { FV }=\beta_{7} \text { MGR }+ \text { e } 2 \\
& \text { TAXSHARE }=\beta_{8} \text { MGR }+\beta_{9} \text { FV }+ \text { e } 3 \\
& \text { BIG6 }=\beta_{10} \text { LPOP }+\beta_{11} \text { TAXSHARE }+ \text { e } 4 \\
& \text { COMPUNIT }=\beta_{12} \text { LNPOP }+ \text { e } 5
\end{aligned}
$$

The final model is summarized in Figure 2. Since all the variables in the model are observed rather than latent variables, they are placed in rectangles. The arrows signify the expected direction of the relationships. Curved lines indicate significant relationships (covariations) across exogenous variables. A theoretical relationship was not anticipated in advance and a directional effect is not obvious. The relationships across the variables are stated as standardized coefficients. For example, the standardized coefficient between log of population and log of audit fees is 58.5. This implies that a one percent increase in population is associated with $0.6 \%$ increased in audit fees. For each equation specified (i.e., an equation is specified for each endogenous variable as shown above), $R^{2}$ is stated in bold. For example, the variance of Big 6 auditor is based on the relationship with log of population and tax share and the $\mathrm{R}^{2}$ of $18.4 \%$ represents the variance in big 6 auditors explained by those variables. The robustness of the SEM model is based on a set of goodness of fit tests described below. 
Figure 2

SEM Model-Based on Standardized Coefficients

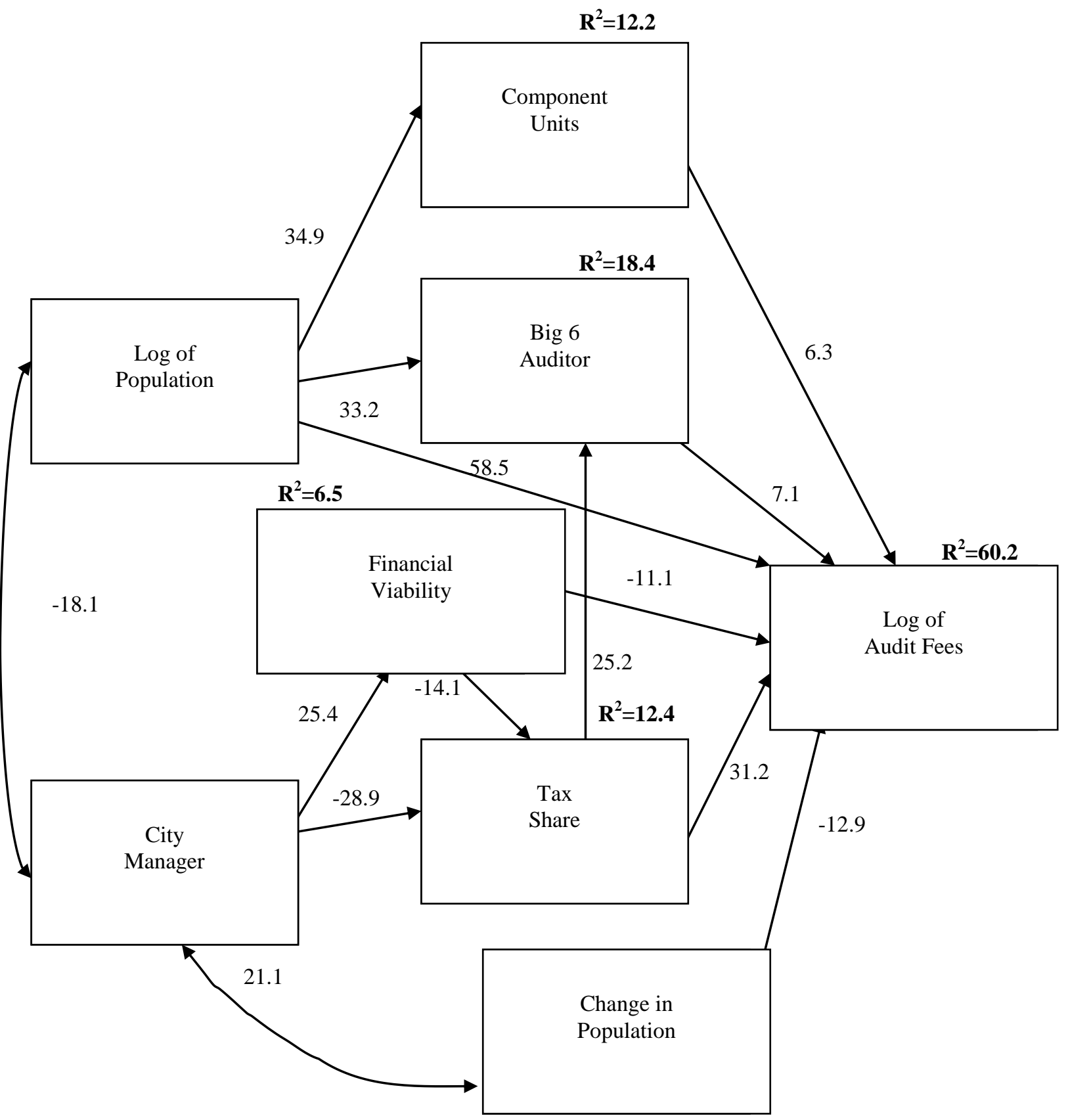

Goodness of Fit Tests:

\begin{tabular}{|l|c|l|c|}
\hline Chi Square & 30.79 & NFI & 0.883 \\
\hline Df & 13 & RMSEA & 0.099 \\
\hline Sign. & 0.0036 & GFI & 0.9501 \\
\hline
\end{tabular}


Seven of the eleven original independent variables are in the final model, as summarized in Figure 2. Four of the theoretical constructs are represented as direct effects of audit fees in the final model: client size as measured by log of population; complexity of client operations as measured by taxshare and component units; financial risk as measured by financial viability and change in population (a demographic factor); and auditing as measured by Big 6 auditor. The directions of the variables are as predicted. The negative sign for change in population suggests that lower (or negative) growth cities require greater audit effort. Alternatively, this may suggest that negative growth cities have higher audit risk. Governance structure as measure by city manager has no directs effect on audit fees, but serves as a mediating factor. The six direct-effects variables had a combined $\mathrm{R}^{2}$ of $60.2 \%$ for audit fees and all goodness of fit tests are highly significant.

There are four indirect effects, with component unit, big 6 auditor, financial viability, and tax share serving as mediating variables. Financial viability increases with the presence of a city manager, while taxshare decreases. This suggests that city managers are more likely to prefer a financial cushion and more likely to rely more on nonlocal revenues (for example, by applying for intergovernmental grants). Log of population is an exogenous variable that has both a direct effect on audit fees and positive indirect effects through component units and big 6 auditors. A larger tax share increases the probability of a Big 6 audit.

There are two significant covariations across the exogenous variables. Log of population negatively covaries with city manager. This suggests that relatively smaller cities are more likely to have a city manager rather than a mayor as the chief executive. City manager positively covaries with change in population. Municipalities using city managers have faster population growth rates than cities with mayors.

The final model is based on a parsimonious model while improving the goodness of fit indices. The goodness of fit tests determine if the tested model should be accepted. The chi square statistic tests the null hypothesis that the model fits the covariance matrix. As a rule of thumb, a chi square dividend by degrees of freedom of less than five (relative chi-square) is a good fit. In this case, it is $30.79 / 13$ or 2.4. Other goodness of fit tests include Bentler \& Bonnett's normed fit index (NFI) with a fit of $88.3 \%$ (a value greater than .80 is considered acceptable, although some authorities suggest .90), root mean square error of approximation (RMSEA) which barely made the .1 cutoff, and the goodness of fit index (GFI) with a fit of $95 \%$ (GFI greater or equal to .90 is considered acceptable). See, for example, Bollen 1989 for an explanation of goodness of fit tests and detailed information on SEM analysis. In general, these measures indicated an adequate model fit.

\section{Comparison to OLS Results}

Table 4

Regression Analysis with Coefficients (t-values) Dependent Variable: Log of Audit Fees

\begin{tabular}{|l|c|c|c|}
\hline \multicolumn{1}{|c|}{ Variable } & Expected Sign & Coefficient & t-value \\
\hline Log of Population & + & .588 & $8.93^{*}$ \\
\hline Tax Share & + & .000 & $4.68^{*}$ \\
\hline Component Units & + & .012 & 1.01 \\
\hline Financial Viability & - & -.262 & $-1.71^{* *}$ \\
\hline Population Change & $?$ & -.770 & $-2.13^{* *}$ \\
\hline Big 6 & + & .120 & 1.29 \\
\hline City Manager & - & -.082 & -0.90 \\
\hline Intercept & & 7.806 & $21.33^{*}$ \\
\hline $\mathbf{R}^{\mathbf{2}}$ & & $64.6 \%$ & \\
\hline F Value & & $34.41^{*}$ & \\
\hline $\mathbf{n}$ & & 140 & \\
\hline
\end{tabular}

* Sign. at .0001; ** Sign. at .1 
The final regression includes the variables from the final SEM model and shown in Table 4. Four of the independent variables are significant: LPOP, TAXSHARE, FV, and CPOP, all in the expected direction. The $\mathrm{R}^{2}$ was $64.6 \%$, slightly larger than for the SEM model. Since the OLS model has all the variables used for SEM, the $\mathrm{R}^{2}$ will almost always be higher than SEM. The OLS results suggest that MGR is irrelevant relative to audit fees, when in fact there are several indirect effects that that are significant. The advantage of SEM is the complete analysis of relationships across all variables, such as the mediation relationship of MGR through several variables.

An alternative to discover a parsimonious OLS model is stepwise regression. This approach resulted in a four variable model, including LNPOP, TAXSHARE, CPOP and FV. These are in the SEM model, but represent an incomplete presentation of fee relationships, since it excludes COMPUNIT and BIG6 plus the indirect effects of MGR and mediating effect of several variables. It's not clear that a "final model" similar to SEM is likely using only an OLS approach.

\section{CONCLUSION}

The objectives of this project were to model municipal audit fees using an audit economics framework and then explore this conceptual framework empirically using structured equation modeling. A sample of large cities using data from 1996 is used for analysis. The theoretical framework uses five constructs to explain audit fees: (1) client size, (2) complexity of client operations, (3) financial risks including demographic characteristics, (4) auditing factors, and (5) governance structure.

Seven variables are in the final model SEM model. Six of these directly explain audit fees: LNPOP, COMPUNIT, FV, TAXSHARE, CPOP, and BIG6. The six direct-effects variables had a combined $\mathrm{R}^{2}$ of $60.2 \%$ and all goodness of fit tests were reasonably significant. MGR has no direct effect on audit fees but influence fees indirectly through three other variables. In addition, COMPUNIT, BIG6, FV, and TAXSHARE serve as mediating variables for other effects.

SEM provides more information on the overall fee structure. Corporate governance as measured by city manager has significant indirect effects through financial viability and tax share, unobservable when using OLS. First, a city manager is more likely to have a larger financial cushion, a measure of fiscal conservatism. Second, a city manager is more likely to rely on intergovernmental grants, which broadens the revenue base and may provide relief to local taxpayers. The other mediating effects work through variables that have significant direct effects, including population size and big 6 auditors, providing additional information on complex relationships.

In summary, the results demonstrate that SEM modeling can be used in the context of explaining audit fees and provides more information on how the highly correlated independent variables are interrelated in the context of explaining audit fee levels.

\section{ACKNOWLEDGMENTS}

We thank Don Dies, Paul Copley and workshop participants at the 2006 Governmental and Not-for-Profit Midyear Meeting and at the 2006 National American Accounting Association Conference for helpful comments and suggestions.

\section{NOTES}

1 See, especially, Baber et al. (1987), Rubin (1988), Ward et al. (1994), Deis and Giroux (1996), Sanders et al. (1995), Copley et al. (1994), and Elder et al. (1999).

2 Several auditing papers used SEM, including Kalbers and Fogarty (1993), Shafer et al. (1999), Johnstone (2000), Shapeero et al. (2003), Donnelly et al. (2003), and Lowensohn (1996). SEM proved quite useful in auditing research in advancing various behavioral theories.

3 In certain specific situations OLS regression is not the preferred estimator in audit fee models. For example, Copley et al. (1995) used simultaneous equations (or two stage least squares) to model both the demand and supply of auditing services. Elder et al. (1999) used a self-selection model to analyze audit 
fees for municipalities that may have also purchased non-audit fees from the same audit firm. We have compared our SEM analysis to OLS as these two unique situations do not apply to our municipal model.

\section{REFERENCES}

1. Baber, W., E. Brooks, \& W. Ricks, An Empirical Investigation of the Market for Audit Services in the Public Sector, Journal of Accounting Research, Autumn 1987, pp. 293-305.

2. Bamber, E., L. Bamber, \& M. Schoderbek, Audit Structure and Other Determinants of Audit Report Lag: An Empirical Analysis, Auditing: A Journal of Practice \& Theory, Vol. 12, No. 2, 1993, pp. 1-23.

3. Bollen, K., Structural Equations With Latent Variables, New York: John Wiley \& Sons, 1989.

4. Cheng, R., An Empirical Analysis of Theories on Factors Influencing State Government Accounting Disclosure, Journal of Accounting and Public Policy, vol. 11, 1992, pp. 1-42

5. Copley, P., M. Doucet, \& K. Gaver, A Simultaneous Equations Analysis of Quality Control Review, Accounting Review, January 1994, pp. 244-256.

6. Copley, P., J. Gaver, \& K. Gaver, Simultaneous Estimation of the Supply and Demand of Differential Audits: Evidence From the Municipal Audit, Journal of Accounting Research, Spring 1995, pp. 137-155.

7. DeAngelo, L., Auditor Size and Audit Quality, Journal of Accounting and Economics, December 1981, pp. 183-199.

8. Deis, D. \& G. Giroux, The Effect of Auditor Changes on Audit Fees, Audit Hours, and Audit Quality, Journal of Accounting \& Public Policy, Spring 1996, pp. 55-76.

9. Donnelly, D., J. Quirin, and D. O’Bryan, Auditor Acceptance of Dysfunctional Audit Behavior: An Explanatory Model Using Auditors' Personal Characteristics, Behavioral Research in Accounting, Vol. 15, 2003, pp. 87-110.

10. Elder, R., S. Kattelus, \& E. Douthett, Audit Fees and Nonaudit Fees in the Governmental Sector: A SelfSelection Analysis, Research in Government \& Nonprofit Accounting, Vol. 10, 1999, pp. 65-86.

11. Giroux, G., R. Jones \& M. Pendlebury, Accounting and Auditing for Local Governments in the U.S. and the U.K., Journal of Public Budgeting, Accounting and Financial Management, Spring 2002, pp. 1-26.

12. Governmental Accounting Standards Board (GASB), 1991. The Financial Reporting Entity, Statement No 14. of the Governmental Accounting Standards Board. Governmental Accounting Standards Board, Stamford, CT.

13. Johnstone, K., Client-Acceptance Decisions: Simultaneous Effects of Client Business Risk, Audit Risk, Auditor Business Risk, and Risk Adaptation, Auditing: A Journal of Practice \& Theory, Spring 2000, pp. $1-26$.

14. Kalbers, L. and T. Fogarty, Audit Committee Effectiveness: An Empirical Investigation of the Contribution of Power, Auditing: A Journal of Practice \& Theory, Spring 1993, pp. 24-49.

15. Lowensohn, S., Determinants of Audit Partner Motivation and the Supply of Governmental Audit Services in Florida, University of Miami Dissertation, 1996, 174 pages.

16. McLelland, A. \& G. Giroux, An Empirical Analysis of Auditor Report Timing by Large Municipalities, Journal of Accounting and Public Policy, Autumn 2000, pp. 263-281.

17. Rubin, M., Municipal Audit Fee Determinants, Accounting Review, April 1988, pp. 219-236.

18. Sanders, G., A. Allen, and L. Korte, Municipal Audit Fees: Has Increased Competition Made a Difference? Auditing: A Journal of Practice and Theory, Spring 1995, pp. 105-114.

19. Selden, S., Brewer, G., Brudney, J., 1999. The Role of City Managers: Are They Principals, Agents, or Both? American Review of Public Administration 29 (2), pp. 124-148.

20. Shafer, W., R. Morris, and A. Ketchand, The Effects of Formal Sanctions on Auditor Independence, Auditing: A Journal of Practice \& Theory, 1999 Supplement, pp. 85-102.

21. Shapeero, M., H. Koh, and L. Killough, Underreporting and Premature Sign-off in Public Accounting, Managerial Auditing Journal, Vol. 18, 2003, pp. 478-489.

22. Simunic, D. 1980. The pricing of audit services: Theory and evidence. Journal of Accounting Research 18 (Spring): 161-190.

23. Smith, D. and Langfield-Smith, K., Structural Equation Modeling in Management Accounting Research: Critical Analysis and Opportunities, Journal of Accounting Literature, Vol. 23, 2004, pp. 49-86.

24. Ward, D., R. Elder, and S. Kattelus. 1994. Further evidence on the determinants of municipal audit fees. The Accounting Review 69 (April): 399-411. 